\title{
Türkiye' de Metropoliten Alan ve Büyükşehir Yönetimi Bakımından 6360 Sayılı Kanunun Değerlendirilmesi
}

\author{
Namık Kemal ÖZTÜRKa, b, Eren TOZAKc
}

\section{Özet}

Metropoliten alan yönetimiyle ilgili pek çok ülkede yeni model uygulama girişimleri gittikçe yaygınlaşmaktadır. Türkiye'de ise tarihi süreç içinde çeşitli fikirler ortaya konmuş ve son yıllarda metropoliten yapının durumu gündemde yer edinerek birtakım tartışmalara zemin oluşturmuştur. 6360 Sayılı Kanun ile Türkiye'de kapsamlı düzenlemeler yapılmış, illerin yönetim yapısında, mali işleyişinde, yerel siyasete katılımında, planlamada ve hizmet sunumunda değişimler meydana gelmiştir. Bu değişimler, yerel yönetimlerin hizmet sunumunda ikili bir yapının ortaya çıkmasına neden olmuştur. Bir yanda il belediyeleri bulunmakta öte yanda yine il mülki idare sınırlarını kendine temel alan büyükşehir belediyeleri bulunmaktadır. Mevcut durumun içerdiği ikilemi ortadan kaldıracak ve bütün ülkede aynı yerel yönetim mantığını temel alacak "bütünşehir" modeline geçiş tartışmaları yaşanmıştır. $\mathrm{Bu}$ geçiş sürecinin sağlıklı ve dengeli bir şekilde gerçekleşmesi için demokratik değerler, halkın katılımı, hizmet kalitesinin yükseltilmesi gibi hususlar ön plana çıkmaktadır.
Anahtar Kelimeler

Büyükşehir

Metropoliten Alan

Bütünşehir

6360

Makale Hakkında

Geliş Tarihi: 30.06 .2021

Kabul Tarihi: 24.09.2021

Doi: 10.18026/cbayarsos.959856

\section{Evaluation of Law No. 6360 in terms of Metropolitan Area and Metropolitan Management in Turkey}

\section{Abstract}

Attempts to implement new models are becoming more common in many countries regarding metropolitan area management. In Turkey, on the other hand, various ideas have been put forward in the historical process, and the situation of the metropolitan structure has been on the agenda in recent years and has prepared the ground for some discussions. With the Law No. 6360, new regulations have been made in the local area in Turkey, and changes have occurred in the administrative structure of the provinces, in the financial system, in their participation in local politics, in the provision of services to the local people and in planning. These changes have led to the emergence of a dual structure in the service delivery of local governments. There are both provincial municipalities and metropolitan municipalities based on the provincial administrative boundaries. There have been discussions about the transition to the "unicity" model, which will eliminate the dilemma of the current situation and will be based on the same local government logic throughout the country. For this transition process to take place in a healthy and balanced way, issues such as democratic values, public participation and increasing service quality come to the fore.
Keywords

Metropolis

Metropolitan Area

Unicity

6360

\section{About Article}

Received: 30.06.2021

Accepted: 24.09.2021

Doi: 10.18026/cbayarsos.959856

a İletișim Yazarı: erntzk@hotmail.com

b Prof. Dr., Muğla Sıtkı Koçman Üniversitesi, İ̈BF Kamu Yönetimi Bölümü, ORCID: 0000-0002-7264-4791

c Doktora Öğrencisi, Muğla Sıtkı Koçman Üniversitesi, SBE Kamu Yönetimi Bölümü, ORCID: 0000-0003-4700-7034 


\section{Giriş}

Türkiye'de metropoliten alanlarda trafik, ulaşım, su sorunu, hayat pahalılığı, hava kirliliği, çevre kirliliği, işsizlik, plansız yapılaşma, asayiş, gecekondulaşma, kontrolsüz göç, eğitim, sağlık hizmetleri, kanalizasyon, yeşil alanların yetersizliği, aşırı kalabalık, sunulan hizmette aksamalar, kapasite ve kaynak yetersizliği gibi sıkıntılı durumların yaşandığı gözlemlenmektedir. Bu sıkıntılara önlem almak ve daha büyük sorunların yaşanmamasını sağlamak amacıyla yeni arayışlar söz konusudur. Yönetimsel anlamda, bütün belediyeleri büyükşehir statüsü içine almayı hedefleyen "bütünşehir" düşüncesi bu arayışlardan biridir. Türkiye'de anakent yönetimi ile ilgili farklı model denemeleri yapılmış, son dönemlerde ise 6360 Sayılı Kanun ile büyükşehir yönetimleri yeniden şekillenmiştir. Ancak nüfus kriteri getirildiği için il belediyelerinin hepsi bu model içine girmemekte ve ikili bir yapı ortaya çıkmaktadır. Bütünşehir uygulamaları ile hem bu sorunun giderilmesi hem de 6360 Sayılı Kanunun uygulamasından kaynaklı sorunların çözülmesi hedeflenmektedir. Bu çalışma Türkiye'de metropoliten alan ve anakent yönetimini düzenleyen 6360 Sayılı Kanuna yönelik ortaya konan görüşleri ele alarak önümüzdeki yıllarda gerçekleştirilmesi düşünülen "bütünşehir" uygulamasına katkı sunmayı amaçlamaktadır.

\section{Metropoliten Alan Yönetimine İlişkin Yaklaşımlar}

Metropoliten alanların kavramsal yönüyle ilgili üç yaklaşım vardır. Bunlar metropoliten reform geleneği, kamu tercihi okulu ve yeni bölgecilik akımıdır (Oktay, 2016, s. 55). Metropoliten reform geleneği, aynı zamanda eski bölgecilik olarak da ifade edilmektedir. Bu anlayış, metropoliten alanlarda büyük ölçekli yönetim yapıları sayesinde yerel hizmetlerin sağlanmasında verimlilik ve planlamada etkinlik olabileceğini öne sürmektedir. Metropoliten reform geleneğini savunanlar, kentsel alanda çok sayıda yönetim birimlerinin etkin olması, eşitlik ve koordineli olarak hizmet sağlama hakkında bazı sorunların yaşanabileceğini öne sürmektedir. Mesela bu anlayışa göre metropoliten alanların sıkıntılarıyla ilgilenmek, birbiriyle bağlantısı olmayan çoğu yönetim birimleri için oldukça zor bir durumdur. Aynı alanda pek çok belediye biriminin olması durumunda insanlar hangi yönetim birimlerinin sorumlu olacağını bilemeyebilir. Ayrıca yönetim birimleri, farklı gerekçeler öne sürerek sorumluluk almaktan kaçınabilir veya sorumluluğu yayarak düşük maliyetli ve kaliteli hizmeti yeterince sağlamayabilir (Özgür, 2008, ss. 6-7).

Bahsedilen sorunların çözümünde kentsel alanlarda bulunan çok sayıda yönetim birimlerinin birleştirilmesiyle kent düzleminde sağlanacak hizmetlere uygun yönetim yapısının meydana getirilmesi düşünülebilir fakat reform yaklaşımına dayalı uygulamaların bazı başarısızlıklara sebep olacağı da söylenebilir (Kübler ve Heinelt, 2005, ss. 9-11). Ne tür başarısızlıklara sebep olacağından bahsetmek gerekirse, özellikle yerel yönetim birimlerinin sayı bakımından az ve mücavir alan, nüfus, kapasite ile kaynak bakımından küçük olan metropoliten alanlarda, birimler arasında hizmet farklılıklarının görüleceği, hizmet kalitesinde düşüş olacağı düşünülmektedir. Ayrıca hizmetlerden sorumlu otoritenin belirlenemeyeceği, ölçek ekonomisinden faydalanmanın zor olacağı, nitelikli personel istihdam etmenin ve belirli alanlarda uzmanlığın sağlanamayacağı savunulmaktadır (Özgür, 2008, s. 6).

Kamu tercihi yaklaşımında yerel yönetim birimlerinin birleştirilerek tek metropoliten yönetim yapısı haline dönüştürülmesine sıcak bakılmamakta olup, metropoliten yerel 
yönetim yapılarının olması savunulmaktadır. Buna göre yönetimler arasında oluşacak rekabetin iyi yanları ortadan kalkacak, tekelci bir yapı oluşacak, bölgesel anlamda merkezi bir yapı ortaya çıkacak ve demokratik kontrol kanalları tıkanıp seçme özgürlüğü azalacaktır (Tiebout, 1956, ss. 416-424). Kamu tercihi yaklaşımında yerel yönetimlerin hareket özgürlüğüne sahip insanları kendilerine çekmek için rekabette bulunması ve hizmet sunumunda kaliteyi artırması düşüncesi söz konusudur. Rekabetin arttığı ortamda yenilikçi akımların oluşması, hizmet kalitesinin artması, katılımın genişlemesi ve hesap verebilirlik ortamının sağlanması açısından olumlu görülmektedir (Oktay, 2016, s. 58-59).

Bölgecilik yaklaşımı, bir kentsel veya metropoliten alanda bulunan çeşitli yerel toplulukların bölgesel ortak çıkarlarını sağlamak amacıyla beraber çalışabilme kapasitesini ifade etmektedir (Gül ve Batman, 2013, ss. 11-12). Bölgecilik anlayışı, kentsel alanlarda esnekliğe ve çeşitliliğe imkan sağlayan bölgesel çaplı hizmet sağlama modellerini savunmaktadır (Kübler ve Heinelt, 2005, s. 10). Ayrıca bölgesel çapta zorunlu yönetimsel yapılar meydana getirilmesi veya çok sayıda ayrışmış durumdaki yönetimler arasında rekabet ortamı sağlanması yerine, mevcut aktörler arasındaki ilişkilerin tekrar ele alınarak, yönetişim anlayışı kapsamında etkinleştirilmesi savunulmaktadır. Yerel yönetim birimleri arasında, üst yönetimlerin gücüne dayanmayan, hiyerarşik yapıda olmayan, etkileşimci ve katılımcı tutumla, anlaşmalar yapılması, hizmet sözleşmelerinde bulunulması, hizmet birlikleri oluşturularak yereldeki insanların ihtiyaçlarının, metropoliten çapta daha iyi giderilebileceği düşünülmektedir (Bae ve Feiock, 2012, s. 162).

Metropolitenleşme aşamasında ilk olarak üretim, yönetim ve denetim işleri çeşitlenmekte, ardından ise yönetimin rutin bölümleri denetimden ayrılmaktadır. Gelişen teknoloji sayesinde geniş alanlara ihtiyaç duyan yönetim ve üretim, çoğunlukla anakentin dişındaki yerlere eğilim göstermektedir. Dışa açılma durumunda öncelikle konut, sonrasında ise sanayi banliyöleri ortaya çıkmaktadır. Kentin metropoliten alanın dışına yayılması durumunda ortaya çıkan büyük yerleşim yerleri metropoliten alan şeklinde ifade edilmektedir. 19'uncu yüzyılın son dönemlerinden itibaren günümüzün gelişmiş ülkelerinde oluşan metropoliten alan anlayışı haberleşme, ulaşım ve üretim teknolojileri kadar bunların gerektirdiği ölçüde farklılaşmanın ve uzmanlaşmanın sonucunda meydana gelmiştir. 20'nci yüzyılın ilk dönemlerinden itibaren bir şekilde kendi kendine yeten uydu kentler ortaya çıkmıştır. Kentin dışına öncelikle çıkanlar büyüklük ve örgütlenme yönünden daha gelişmiş olan girişimlerin üretim ve rutin yönetim işlemleri söz konusuyken, mali yönden karar verme ve denetim fonksiyonuyla uzmanlaşmış mesleki hizmetler ise merkezde bulunmaya devam etmiştir. Böylece metropoliten alan, konut alanlarıyla kentin sanayi ve konut banliyölerinden yoğun nüfusa ulaşmalarına ilişkin kent merkezine bağımlılığını sürdüren özel sanayi kentlerinden, metropolün gereksinimlerini gidermeye eğilim göstermiş tarımsal işletmelerle civarlarındaki kırsal alana hizmet sağlayan farklı hizmet merkezlerinden meydana gelmektedir (Türel ve Günay, 1987, s. 115).

Metropoliten alan, ekonomik, toplumsal, politik ve idari etkenler sebebiyle büyükşehir ve ona bağlı kısımları ifade etmektedir. İçinde bulundukları kentsel alanlarda farklı kıstaslar bakımından kent üstü mekanlar şeklinde ifade edilebilir. Gelişmekte olan ülkelerde ise kentsel hayatın sunduğu kolaylıklar cazipliği, sanayi ile ticaretin yoğunlaşması ve istihdam koşullarının diğer yerlere kıyasla yüksek olması metropollere olan göçü artırmıştır. Metropoliten yönetim hakkındaki yeni fikirler, aslında metropoliten alanlarda merkeziyetçi veya yerinden yönetimi savunan yaklaşımların tercih edilmesinin oluşturacağı sonuçlar 
açısından ortaya çıkacaktır. Önceden belirlenen birtakım kıstaslar kapsamında kamu hizmetlerinin eşit olarak sağlanması, kaynakların eşit olarak tahsis edilmesi, hizmetlerin etkin yönetimi, kent planlaması ile kamu politikalarının oluşturulmasına ilişkin bütünsellik bakımından merkezi yönetim gerekçeleri olurken vatandaşların katılımı, halka yakınlık, yerel toplulukların çıarlarının gözetilmesi yerel demokrasiyi öne çıkaran küçük yerel yönetimlerin ana dayanakları olarak söylenebilir (Erençin, 2005, ss. 122-123).

Kentlerin büyümesi, yerel halkın artan istekleri, büyükşehirlerde oluşan sıkıntılar, bu sıkınıtların çözüme kavuşması için işlevsel ihtiyaçlar kapsamında yönetim modellerinin şekillendirilmesi ihtiyacını ortaya çıkarmıştır. Fakat büyükşehir alanlarının gelişim gösterdiği yerlerde bütün bölgenin tek otorite tarafından yönetilmesi zorlaşmaktadır (İsbir, 2012, s. 72). Bu durumda büyükşehir yönetimlerine ihtiyaç duyulma sebebi sorgulanmalıdır. Metropoliten alanlarda kent bütününde planlama, altyapı, ulaşım ve ekonomik yönden bütünleşmenin sağlanması bakımından metropoliten alan büyüklüğüne ilişkin yönetim sisteminin gerekliliğini öne çıkarmaktadır. Yüksek teknoloji ve bununla bağlantılı olarak yüksek yatırım gerektiren durumlarda alt ölçekteki belediyelerin yeterli kaynaklara ilişkin eksikliklerinin giderilmesi önem taşımaktadır.

Türkiye'deki metropolleşme sürecinin, gelişmiş ülkeler ile kiyaslandığında daha geç dönemlerde başladığı ve kendine özgü yapılara sahip olduğu söylenebilir. 50'li yıllardan itibaren çok partili döneme geçiş, sanayi yatırımlarının ülke geneline yayılması, ulaşım ağlarının genişlemesi gibi gelişmelerle beraber kırsaldan kent merkezlerine olan göç kentlerde yoğun nüfus yığılmalarına yol açmıştır. Bu kentler göçün hız kazanmasıyla, kontrol altında tutulamayan kentleşme süreciyle beraber altyapı yetersizliği, gecekondulaşma, toplumsal ve çevresel sıkıntıların görüldüğü metropollere dönüşmüştür. Bu dönüşüm ilk olarak İstanbul, Ankara ve İzmir'de yaşanmıştır. Bu şehirler planlama, imar, şehir toprağının kullanılması, konut, belediye hizmetleri, ulaşım, alt yapı ihtiyaçlarının artması, çevresel sıkıntılar gibi pek çok sorunla karşılaşmak durumunda kalmıştır.

Türkiye'de kentsel bölgelerin yerel yönetim bakımından bütünleştirilmesi yönünde yürürlüğe konan ilk düzenleme 1980 tarihli 34 Sayılı Milli Güvenlik Konseyi Kararı, ikinci düzenleme 1984 tarihli 3030 Sayılı Kanun, üçüncü düzenleme ise 2004 tarihli 5216 Sayılı kanuni düzenlemedir. 3030 Sayılı Kanun sayesinde metropoliten niteliğe sahip kentler diğer kentlerden ayrı değerlendirilerek büyükşehir olarak tanımlanmıştır. Sonrasında metropoliten kent etkisinde kalan mücavir alanda bulunan küçük ve orta ölçekli belediyeler gibi yerleşim yerlerinin anakent ile plan bütünlüğü ve denetimi haricinde mevzuata dayalı bağımsız plan uygulamalarına sebep olmuştur. Çevre yerleşim yerlerinde değişimler yaşanmış ve bu değişim süreciyle beraber birbirinden farklı özelliklere sahip yerleşim yerleri meydana gelmiştir. Kırsal, yarı kentsel, kentsel özelliklere sahip olan bu yeni yerleşim yerleri ilerleyen zamanda metropoliten kentin parçası haline gelmektedir. Ayrıca Avrupa Birliği'ne uyum süreci, kentlerin yönetimine yönelik yeni düzenlemelerin yapılmasını gündeme getirmiştir (Yenigül ve Çamur, 2012, ss. 96-97). Metropoller kentleşme sürecinde ekonomik, toplumsal ve fiziksel bakımdan yüksek yoğunluğa sahip mekansal alanlara dönüşen yerlerdir. Özellikle son zamanlarda hizmet sektöründe ve sanayi bölgelerinde yaşanan gelişmeler kentlerde nitel ve nicel açıdan değişimlere sebep olmuş, böylelikle geleneksel kent yapısından farklı olarak metropoliten kent yapıları ortaya çıkmıştır (Kıray, 1998, ss. 16-23). 


\section{Metropoliten Alan ve Türkiye'deki Gelişimi}

Metropoliten alan olarak ifade edilen yerler, merkezde bulunan anakent ile anakenti çevreleyen ve ekonomik bakımdan bütünlük kuran yöre kentlerle ilçelerin yerel yönetim birimlerinden oluşmaktadır (Frey ve Zimmer, 2001, ss. 7-8). Anakent, metropoliten alan, metropol, metropolis, büyükşehir gibi kavramlar genellikle birbirinin yerine kullanılmaktadır. Metropoliten alan, genel anlamıyla nüfusun yoğunluğunun bulunduğu ekonomik, toplumsal ve idari bakımdan bir bölgenin merkezi konumunda olan merkezi şehir veya şehirlerin çevre kentleriyle oluşturdukları birim olarak ifade edilmektedir (Görmez, 1993, s. 1).

Metropolis kelimesi Yunanca kökenli olup "metro" yani ana veya asıl ile "polis" yani kent kelimelerinin birleşmesiyle meydana gelmiş, antik dönemde şehir devletlerini ifade etmek için kullanılmıştır. Yakın dönemde ise bu kelime İstanbul, Londra, Tokyo, New York gibi büyük yerleşim alanlarını tanımlamak amacıyla kullanılmıştır (Soyda ve Türk, 2012, s. 51). İngilizce karşıllğı "metropolitan municipality" olan kelime dilimizde büyükşehir veya anakent kelimeleriyle ifade edilmektedir. Kavram üzerinde net olarak fikir birliği olmamasında asıl etmen kavramın ekonomik, toplumsal, politik ve idari katmanlarının varlığından kaynaklanmaktadır. Çoğu ülkede olduğu gibi kentleşme, gelişmekte olan ülkelerde hızlı gelişim göstermektedir. Hızla büyüyen şehirlerde belediye sınırlarının dışında düzensiz ve plansız gelişmeler olunca anakentlerde özel model arayışları gündeme gelmiştir. Bundan dolayı anakentlerin yönetiminde tek kademenin bulunduğu kent yönetimleri, iki kademenin bulunduğu anakent yönetimleri, özel yönetim bölgeleri ve yönetimler arasındaki işbirliği süreçlerinden oluşan çeşitli yönetim biçimleri söz konusudur (Özer ve Akçakaya, 2014, s. 97).

Dünyanın farklı yerlerindeki metropollerin sahip olduğu yapısal farklılıklar, metropol hakkında net tanımlama yapmayı zorlaştırmaktadır. Mesela kentsel altyapılardaki gelişmişlik durumları, lüks tüketim eğilimleri, büyük kapsamlı finans kurumları, iş sahaları, konut alanları, tarım dışı sektörlerin yoğunluk göstermesi gibi hususlar dünyanın pek çok yerinde metropol olarak ifade edilen yerlerde farklılıklar göstermektedir (Oktay, 2016, ss. 5152). Metropoliten alanın sınırlarının neler olduğu hakkında ülkeler birbirinden çeşitli ölçütlere sahiptir. Dolayısı ile büyükşehir, metropol, anakent gibi kavramların tanımlanması üzerine ulusal ve uluslararası düzlemde tam anlamıla uzlaşmanın olduğunu söylemek güçtür.

Bütünşehir kelimesi aslında merkezde bulunan büyük belediyenin, etrafındaki küçük yönetim unsurlarını içine alarak genişlemesini ifade etmektedir (Zengin, 2014, s. 111). Büyükşehir belediye sınırlarının il mülki sınırları ile çakıştırılarak oluşturulan yeni yönetim tarzı bütünşehir olarak isimlendirilmektedir. 1984 tarihli 3030 Sayılı Kanunun yürürlüğe girmesiyle birlikte anakentlerin etrafındaki küçük belediyelerin belediye hizmetlerinin yeterince sağlanamaması ile kontrol ve iç güvenlik hakkında duyulan hassasiyet sebebiyle bu tanım ortaya çıkmıştır (Tekin, 2018, ss. 90-93).

Osmanlı İmparatorluğu'nun ilk dönemlerinden Tanzimat dönemine kadar geçen süreçte kadılar, mimar ağaları, vakıflar, esnaflar gibi kişiler veya kuruluşlar tarafından sağlanan belediye hizmetlerinin sürdürülmesi için tek merkezli bir yapı bulunmamaktaydı. Yerleşim yerlerinde ortaya çıan yapısal değişiklikler ve Batılılaşma akımıyla birlikte yapılan reformlar belediyelerin oluşumuna temel hazırlamıştır. Osmanlı şehirlerindeki belediye 
hizmetlerinin yetersiz olması sebebiyle İstanbul'da yaşayan Avrupa kökenli insanlar şehir düzeniyle ilgili hizmetlerin daha iyi sağlanabilmesi amacıyla belediye yapısına ihtiyaç duyulduğunu dile getirmiştir. Bu tavsiyenin etkisiyle 1855 yılında "Şehremaneti" yani İstanbul Belediyesi kurulmuştur. İstanbul'un tamamında belediye yapilanmasının zor olacağ 1 düşünülmüş, ilk olarak şehrin bir bölgesinde uygulanmasına, ilerleyen süreçte ise diğer kısımlarda yapılanmanın sağlanmasına karar verilmiştir. Ancak tüm çabalara karşın İstanbul'un tamamında belediye yapılanmasının sağlanamamasıyla 1877 yılında Osmanlı Meclisi tarafından Dersaadet Belediye Kanunu kabul edilmiştir. 1877 yılında kabul edilen Vilayetler Belediye Kanunu ise diğer şehirlerde ve kasabalarda belediyelerin kurulmasına temel oluşturmuştur. Belediye yönetimiyle ilgili olan bu işleyiş 1930 tarihli 1580 Sayılı Belediye Kanununun yürürlüğe girmesine kadar sürmüştür (Eryılmaz, 2009, ss. 187-190).

Belediye hizmetleri, Cumhuriyetin ilk dönemlerinde valilikler tarafından sağlanmıştır. Türkiye'de büyük kent alanlarının farklı bir kanunla yönetilmesi gerektiği, 1924 tarihli 442 Sayılı Kanuna kadar dayanmaktadır. Bu kanun kapsamında ilerleyen yıllarda üç çeşit büyüklüğe sahip belediyeler hakkında ayrı kanunlar çıkarılması düşüncesine yer verilmiştir. Bunlar, kasabalar, belediyeler ve büyükşehir belediyeleri olarak ifade edilmiştir (Aytaç, 1990, s. 90). İlerleyen dönemlerde 1930 tarihli 1580 Sayılı Kanun yürürlükte iken, büyükşehir yönetim denemelerinde bulunulmuştur. Bu çerçevede İstanbul Belediyesi ve il özel yönetimi birleştirilmiş, merkezden bir vali atanarak, belediye başkanı görevini üstlenerek ortak yönetimin başına getirilmiştir (Keleş, 1985, s. 73).

Türkiye'de sanayileşmenin hiz kazanmasıyla birlikte insanların belli bölgelerde yoğunlaşmaya başlaması şehirleşme yolunda dönüm noktasını oluşturmuştur. Bu gelişme, şehir yönetimlerinin hizmet sunumuyla ilgili etkinliğini ve üretkenliğini oldukça sıkıntılı hale getirmiştir. İstanbul, Ankara ve İzmir gibi büyükşehirlerin civarlarında yeni yerleşim yerleri oluşmuş, bu yerlerin yönetim birimleri ile merkezdeki belediye arasında karmaşıklığa zemin oluşturan toplumsal, ekonomik ve politik ilişkiler meydana gelmiştir. Ancak vatandaşların ihtiyaçlarının karşılanması ve vatandaşlara hizmet sunulması bakımından merkezin hizmet kalitesi düşük düzeyde seyretmiştir. Metropoliten alanlarda hizmetlerin nitelik bakımından farklı ellerden sağlanması kaynak israfıyla birlikte hizmet kalitesinin düşmesine neden olmuştur. Bundan dolayı bahsi geçen sorunların çözüme kavuşması için yeni kent yönetim modeli olan büyükşehir yönetimleri kurulmuştur (İnceoğlu, 2012, ss. 119120).

Türkiye'nin sahip olduğu merkeziyetçi yapı, hızla gelişen düzensiz ve plansız kentleşmeye çare olamamış, bu sebeple yeni yönetim modelleri aranmıştır. Yerel yönetimlerin 1961 Anayasası tarafından belediyeler, köyler ve il özel idareleri biçiminde tanımlamasından dolayı yerel yönetimlerin sayısı artmış ve gereğinden fazla yerel yönetim birimini bünyesinde barındıran yapılar oluşturulmuştur (Ertaş, 2016, s. 90). Türkiye' de 12 Eylül 1980 tarihinde gerçekleştirilen askeri darbe sonucunda ülke idaresini ele alan askeri yönetim nüfusun hızla artması ve göçlerin hız kazanması sonucunda büyükşehirlerin etrafında kurulan belediyeler, bölge halkına yönelik görevlerini tam anlamıla yerine getiremedikleri, bundan dolayı civardaki belediyelerin sıkıyönetim komutanlıkları yönetiminde merkez belediyeye bağlanacaklarına dair 1980 tarihli 34 numaralı kararı almıştır. Bu durum büyükşehir yönetimine geçiş için önemli bir gelişme olarak görülmektedir. Türkiye'de büyükşehir yönetimleriyle ilgili 1982 Anayasası'nın 127'nci Maddesinin vermiş olduğu yetkiyle büyükşehir yerleşimleri için özel yönetim biçimleri oluşturulması yönünde 
düzenlemeler yapılmış, 1984 yılında büyükşehir belediyeleri konusunda önemli adım atılmıştır (Derdiman, 2012, s. 52). Büyükşehir yerleşimleri için özel yönetimler kurulabileceğine dayanılarak 3030 Sayılı Kanunla İstanbul, Ankara ve İzmir için nüfus kriteri konmadan iki kademeli belediye kurulmuştur.

1986 ile 1987 yıllarında Gaziantep, Bursa, Adana, Konya, Kayseri büyükşehir statüsüne kavuşmuştur. Merkez ilçeler, ilçe belediyesi şeklinde kabul edilmiştir. 1993 yılında Eskişehir, Diyarbakır, Mersin, Antalya, İzmit, Samsun ve Erzurum büyükşehir statüsüne kavuşmuştur. Bu şehirlerde merkez belediye sınırlarında birden çok ilçenin olması şartı aranmamıştır. Alt kademe olarak ifade edilen yeni yapı meydana getirilmiştir. 2000 yılında Sakarya'da Adapazarı Büyükşehir Belediyesi kurularak, hem ilçe hem de alt kademe belediyelerinin oluşturulması şeklinde karma yöntem uygulanmıştır (İzci ve Turan, 2013, ss. 123-125).

2004 yılında 5216 Sayılı Kanun ile birlikte yerel yönetimlerde yeni sürece girilmiş, büyükşehir belediyesi sınırlarına ölçek ve nüfus kriteri getirilerek alan genişletmeleri yapılmıştır. Bu kanunda İstanbul ve Kocaeli dışındaki belediyeler için kıstaslar getirilmiştir. 5216 Sayılı Kanunun geçici 2'nci Maddesi ile valilik binası merkez alınarak il mülki sınırlarında nüfus göz önüne alınarak belirlenen yarıçaplarda daireler çizilerek büyükşehir alanları genişletilmiştir. Fakat atılan bu adımlara karşın büyükşehir belediyelerinde demokratikleşme ve yerelleşme ile ilgili hedefler beknenen seviyeye ulaşamamıştır (İzci ve Turan, 2013, s. 125). 2004 yılındaki alan genişletmesi alt kademe belediye sayısını oldukça artırmıştır. Çok sayıda belediye ile işbirliği içinde çalışılması kolay olmamış, etkili yönetimin sağlanmasını zorlaştırmıştır. 2008 yılında 5747 Sayılı Kanun ile birlikte bazı büyük ilçeler bölünmüş, bazı küçük beldeler birleştirilerek ilçelere dönüşmüş ve ilçe belediyelerine dahil edilen bazı küçük belediyelerin tüzel kişilikleri kaldırılmıştır. Bu sayede alt kademede ilçe belediyelerinin ve üst kademede büyükşehir belediyelerinin olduğu yalın bir yönetim yapısının olması tasarlanmıştır. 5747 Sayılı Kanuni düzenlemenin ve 5216 Sayılı Kanunun yol açtığ1 alan genişletmelerinin olumsuz etkilerini gidermek amaciyla yapıldığ düşünülmektedir (Arıkboğa, 2013, ss. 59-61). Kentleşmenin dinamik süreç içinde ilerlemesi, yeni gereksinimlerin ve hizmet beklentilerinin oluşması, nüfus artışı, hızla artan göç hareketleri, teknolojinin ilerlemesi, sosyo-ekonomik göstergelerin değişmesi, küreselleşme, insan odaklı yönetim yaklaşımının öne çıkması gibi gelişmelerle birlikte Türkiye'de yerel yönetim sisteminde değişimlere ihtiyaç duyulmuş, 2012 yılında 6360 Sayılı Kanunun çıkarılması ile belediyecilik alanında birtakım yenilikler yaşanmıştır.

\section{Sayılı Kanun Sonrası Gelişmeler}

6360 Sayılı Kanun ile yönetim yapısında, mali sistemde, siyasal coğrafya, temsil, katılım, hizmet sunumu, imar, planlama gibi konularda önemli düzenlemeler yapılmıştır. 2012 yılında çıkarılan 6360 Sayılı Kanun sayesinde büyükşehir sayısı 29 olmuştur. 2013 yılında çıkarılan 6447 Sayılı Kanun ile Ordu ili büyükşehir olmuş ve böylece toplamda 30 il büyükşehir belediyesi statüsüne geçirilmiştir. Bu kanuni düzenlemelerle büyükşehir belediye sınırları il mülki sınırları haline getirilmiş, bu illere bağlı ilçelerdeki köylerin, bucakların, belde belediyelerin ve il özel idarelerin tüzel kişiliği kaldırılmıştır (Arıkboğa, 2013, ss. 48-96).

Tüzel kişiliklerin bazılarının sona erdirilerek yeni tüzel kişiliklerin oluşturulması, yönetimsel bağlılık, sınır değişiklikleri ile yetki bölüşümü kanunun yönetim alanına yönelik yapılan 
düzenlemelerdir. Alınacak payların belirlenmesi ve yeni bölüşüm planı kanunun mali alanına yönelik düzenlemelerdir. Siyasal coğrafyada yaşanan değişimlerle seçim çevresinin değiştirilmesi, temsil ile katılım bakımından meydana gelen değişimler kanunun siyasal alanına yönelik düzenlemelerdir. Mülki sınırlarla belediye sınırlarının örtüştürülmesiyle hizmet alanında genişleme yaşanması, imar ve planlama önde gelmek üzere büyükşehir belediyelerinin hizmetlerine yönelik yapılan değişiklikler kanunun hizmet sunumuna yönelik düzenlemelerdir. Bu değişimlerle birlikte büyükşehirlerde fiziki, sosyal, ekonomik ve idari ilişkiler yapılandırılmıştır. Büyükşehir olan şehirlerde, köyler mahalleye dönüştürülmüştür. Büyükşehir belediyesi olan illerde belde belediyeleri, mahalleleri ile beraber bağlı oldukları ilçe belediyesinin sorumluluk alanına girmiştir.

Büyükşehir belediye sisteminde yaşanan değişimin getirilerinden biri hizmet sağlama konusunda belediyeler arası görev ve yetki paylaşımıyla ilgilidir. Bu düzenleme sayesinde 30 büyükşehirde iki kademeli belediye sistemi meydana gelmiştir. Büyükşehir belediyesi ile ilçe belediyeleri arasındaki görev ve yetki paylaşımına yönelik değerlendirmeler yapıldığında, büyükşehir belediyeleri büyükşehir sınırları içinde aynı yörede yaşayanların ihtiyaçlarının giderilmesi açısından pek çok yetkiye kavuşmuştur. İlçe belediyelerine ise büyükşehir belediyelerine verilen görevlerin dışında az miktarda görev verilmiştir (Üçer vd., 2014, s. 39).

Büyükşehir belediyesi sınırları içindeki ilçe belediyeleri, diğer illerdeki ilçe belediyelerinden farklı özellikler taşımaktadır. Büyükş̧ehirde olmayan ilçe belediyesi, hizmetlerini herhangi bir idari yapılanmanın altında olmadan tek başına sağlayabilmektedir. Ancak büyükşehir belediyesi sınırları içinde bulunan ilçe belediyeleri, belediye hizmetlerinin bazılarını büyükşehir belediyesine devretmekte, bazılarını büyükşehir belediyesiyle paylaşmaktadır. Büyükşehir belediyeleri, ilçe belediyelerinin imar uygulamalarını denetleme konusunda yetkiye sahiptir. Denetleme yetkisi, konuyla bağlantılı tüm bilgiyi veya belgeyi talep etmeyi, araştırmayı, gerektiğinde nüshalarını almayı kapsamaktadır. Bunların yanı sıra imar ıslah planları ile parselasyon planlarının yapılması, ticari işletmelere ruhsat vermek, toptancı hallerinin ve mezbahaların yapılması ile işletilmesi gibi birtakım hizmetlerin büyükşehir belediyesi tarafından onaylanması, denetlenmesi ve bunlardan elde edilecek gelirlerin bir bölümünün büyükşehir belediyesine aktarılması gibi gelişmeler söz konusudur. Vergi gelirleri bakımından ele alındığında ilçe belediyelerinin gelirlerinin \%40'1 büyükşehir belediyelerine aktarılmaktadır. Bu tür düzenlemelerle ilçe belediyelerin kısıtlandığı söylenebilir.

Büyükşehir belediye sınırları içindeki belde belediyeleri kapatılarak bağlı oldukları ilçeye mahalle olarak bağlanmış, bunların personelleri, mal varlıkları, borçları ve alacakları bağlandıkları belediyeye aktarılmıştır. Büyükşehir belediyeleri, il içinde altyapı, tarım, kentsel planlama, imar, ulaşım, toplu taşıma, mezarlık hizmetleri, toptancı halleri, mezbahalar, itfaiye, zabita hizmetleri, arıtma tesisleri, su ve kanalizasyon işleri gibi konularda asıl yetkili konuma gelmiştir. Bunların dışında kentsel dönüşüm, afet işleri, çevre koruma, ana arter yollar, ulaşım planı, otopark hizmetleri gibi alanlarda görevlidir (Gül ve Batman, 2013, s. 33).

6360 Sayılı Kanun ile Türk yerel yönetim sistemine il mülki sınırları içinde hizmet verecek büyükşehir belediye modeli getirilmiş ve geniş ölçekte hizmet verebilen yerel yönetim birimleri öngörülmüştür. Bu yönetim birimlerinde gelişmiş teknolojiler kullanılarak ve nitelikli personel istihdam edilerek verimlilik artışının sağlanması hedeflenmiştir. 
Sağlanacak kaynakların il sınırları içinde bütünleştirilmiş yerel yönetim birimleri arasında etkin kullanımının sağlanması öngörülmüştür. İmar, planlama, ulaşım, itfaiye gibi geniş kapsamda koordineli olarak bütünlük içinde sürdürülmesi gereken, aynı yörede yaşayan insanlara kamu hizmetlerinin verilmesinde etkinliğin sağlanabilmesi, düzenleyici üst imar planları kapsamında il genelinde imar uygulamalarının gerçekleştirilebilmesi amaçlanmıştır (Çelikyay, 2014 s. 12).

6360 Sayılı Kanun sonrası 30 büyükşehirde merkezi idarenin taşrada yürüttüğü hizmetleri sağlamak, hizmette aksamalara yol açmamak, denetim alanındaki boşlukları tamamlamak, afet ve acil yardım hizmetlerini sağlamak amacıyla valilik çatısı altında Yatırım İzleme ve Koordinasyon Başkanlığı (YİKOB) kurulmuştur. Bu düzenleme sayesinde özel idarelerin tüzel kişiliğinin sona erdirilmesinin ardından oluşan boşluğun doldurulması, büyükşehir belediyelerinin olduğu yerlerde kamu kurum ve kuruluşlarının yatırımlarının ve hizmetlerinin etkin olarak yapılması, takip edilmesi ve koordinasyonun sağlanmasının hedeflendiği ifade edilebilir.

6360 Sayılı Kanunun uygulanışı hakkında büyükşehir belediyeleri ile büyükşehir sınırları içindeki ilçe belediyeleri arasında görev, yetki ve kaynak paylaşımı hakkında muhtelif görüş ayrılıklılarının ortaya çıtı̆̆ı gözlemlenmiştir. Çoğunlukla büyükşehir belediyeleri görev ve yetki paylaşımının dengeli yapıldığını savunurken ilçe belediyeleri bunun tersi olduğunu savunmaktadır. Büyükşehir belediyeleri imar ve planlama yetkilerinin kendilerine verilmesiyle daha doğru kararların alınıp uygulanabileceğini savunurken ilçe belediyeleri 1/5000'lik imar planlarının kendileri tarafından düzenlenmesini savunmaktadır. İlçe belediyeleri su hizmetleri, otogar, otopark, mezarlık, itfaiye, toptanci halleri gibi hizmetlerin kendileri tarafından sağlanması gerektiğini, bu hizmetlerin büyükşehir belediyelerin sorumluluğuna verilmesiyle beraber gelir kaybına uğradıklarını öne sürmektedir. Bazı büyükşehir belediyeleri tarafından kırsal alanların büyükşehir belediye sınırları içine alınmasının bütünsellik bakımından önemli olduğu düşünülürken bazı büyükşehir belediyeleri bu durumun tam anlamıyla verimli olmadığını, teşkilat yapılanması bakımından aksamaların yaşandığını ve ekonomik yönden verimsiz olduğunu öne sürmektedir. İlçe belediyelerinin çoğunluğu da bu konuda yeni düzenlemelerin yapılaması gerektiğini dile getirmektedir. Büyükşehir belediyeleri, belediye hizmetlerinin birlik ve koordinasyon içinde sürdürüldüğünü belirtmiş fakat ilçe belediyeleri ihtiyaçların yerinde tespit edilmesi gerektiğini ve insanların yetkili kişilere veya kurumlara kısa sürede kolaylıkla ulaşabilmesi gerektiğini savunarak ilçe belediyelerinin daha fazla güçlendirilmesi gerektiğine vurgu yapmaktadır. Hatta hizmetlerin etkin ve dengeli bir şekilde sürdürülmesi amacıyla merkez ilçe ile merkez dışında kalan ilçelerin bir tutulmaması, görev, yetki ve kaynak aktarımı konularında farklılıklara sahip olması gerektiğine dikkat çekilmiştir (Çapar ve Demir, 2017, ss. 50-78).

\section{Sonuç ve Öneriler}

6360 Sayılı Kanun, yerel hizmetler bakımından imkanların artırılması, kalitenin yükseltilmesi, tasarruf sağlanması, ölçek ekonomisinden yararlanılması ve demokrasinin daha işlevsel hale getirilmesi hedefiyle oluşturulmuştur. İl özel idarelerinin kaldırılarak görevlerinin büyükşehir belediyelerine aktarılıp hizmetlerin tek merkezden sağlanacak olması hizmette etkinlik, verimlilik ve kaynak kullanımı bakımından önemlidir. Yeni ölçek 
düzenlemesi ve hizmet sunum kapasitesinin geliştirilmesi sayesinde büyükşehir sınırları içinde verimliliğin artmasıyla birim başına hizmet maliyetlerinin düşeceği, kaynakların daha verimli kullanılacağı, insan kaynakları kapasitesinin ve karar organlarında bulunan seçilmiş temsilcilerin çeşitliliğinin artacağı, uzmanlaşmış komisyonların oluşturulacağı tahmin edilmektedir. Hizmetlerin sağlanması amacıyla araç, gereç ve donanım unsurlarının sayı ve kalite bakımından iyileştirilerek verimliliğin artması, hizmetlerin sağlanmasında yüksek teknolojik olanaklardan faydalanılması mümkün olabilir. Ayrıca işbölümü sayesinde uzmanlaşma sağlanarak kentin bütününü içeren imar planlarının hayata geçirilmesiyle büyük ölçekli projelerin önü açlabilir. İşleyişteki koordinasyon eksikliklerinin önüne geçilmesi durumunda hizmetlerin daha hızlı ve etkili sunulması, şehrin çeşitli yerlerinde yaşayan vatandaşlara eşit özelliklerde hizmet verilmesi, il genelinde kaynakların kullanılmasında daha adil olması, hizmetlerden faydalanan vatandaşların memnuniyet seviyesinin artması mümkün olabilir. Büyükşehir belediyelerinin olanakları ve seçim sorumluluğuyla hareket etmeleri köylere ve kırsal yerleşim yerlerine sağlanan hizmetlerin daha etkin ve kaliteli olması bakımından rekabeti artırabilir.

Hukuki anlamda köylerin mahalleye çevrilmesi, köylerin kırsal ve toplumsal niteliğinde değişime yol açmamıştır. Mahalleye dönüşen köylerde yaşayan insanların ihtiyaçları kentin diğer alanlarında yaşayan insanlardan farklı özellikler taşımaktadır. Dolayısıyla yeni sistemde bu alanların büyükşehir belediyesi tarafından yönetilmesi, sorunların hızlı çözüme kavuşturulabilmesi açısından sıkıntılı olabilir. İl sınırlarının bütününe yönelik tek merkezden faaliyet gösteren büyükşehir belediyesinin kırsal ve kentsel alanları tek merkezden yönetmesi durumunda merkeziyetçiliğin yerel düzeyde daha da güçleneceği söylenebilir. Büyükşehir belediye sınırları içinde hizmet sunulacak alanın ve nüfusun artması erişilebilirliğin azalmasına, özellikle kırsal yerleşim yerlerine ilişkin sağlanacak hizmetlerin etkin ve verimli olmamasına yol açabilecektir. Büyükşehir belediyesinin sorumluluk alanının il mülki sınırları olarak genişletilmesi sebebiyle uzak ilçelerde ve kırsal mahallelerde yaşayan insanların büyükşehir belediyesine ulaşması zorlaşmıştır. Bu gelişme yerel demokrasi ve halk katılımı açısından sıkıntı oluşturabilir.

Belediye yönetimlerinin, kentsel yerleşme mekanlarının yönetimi olduğu göz önüne alınırsa, mülki sınırların yerel hizmetler bakımından uygun olmadığı, siyasi ve idari kıstaslarla sınırları ortaya konan mülki idare ile yerel hizmetler kıstasına göre sınırları belirlenen mahalli idarenin hizmet ve yönetim kıstaslarının birbirine göre farklılıklar içerdiği görülmektedir. 6360 Sayılı Kanunun 11. Maddesi ve 5216 Sayılı Kanunun 27. Maddesinin birinci fıkrasında yapılan değişiklikle "büyükşehir belediyesi ile ilçe belediyeleri veya ilçe belediyelerinin kendi aralarında hizmetlerin yürütülmesi konusunda ihtilaf çıması durumunda, büyükşehir belediye meclisi yönlendirici ve düzenleyici kararlar almaya yetkilidir" ibaresi eklenmiştir. Dolayısıyla büyükşehir belediyelerinin koordinatör özelliği belirginleşmiştir. Ancak büyükşehir belediyesinin, ilçe belediyesinin ve belediye meclisinin aralarındaki denge bakımından, alınacak kararlarda bazı uyuşmazlıkların çıkabileceği söylenebilir. Mesela büyükşehir belediyeleri ile ilçe belediyelerinin bağlı oldukları siyasi partinin, sahip oldukları siyasi duruşa veya görüşe göre uygulamada çeşitli gelişmelere sebep olabilir. Büyükşehir belediyesi ile ilçe belediyesinin mensup oldukları siyasi partinin aynı olması halinde işbirliğinin artması, farklı siyasi partiye mensup olmaları halinde ise birbirlerine destekte bulunmamaları, hatta birbirlerine engel olmaları gibi olumsuz durumların yaşanması olasidir. 
6360 Sayılı Kanun sayesinde büyükşehir belediyelerine ülkemizdeki yerel yönetim birimleri arasında kamu hizmetinde bulunma hususunda önemli roller verildiği açıktır. Çok sayıda yerel yönetim birimlerinin olması sebebiyle meydana gelen kaynak israfının önüne geçmek, optimal ölçekte hizmet sunmak, hizmetleri geniş düzlemde tek merkezden sunarak ölçek ekonomilerinden faydalanmak gibi amaçlar hükümet tarafından amaçlar ortaya konmuştur. Yerel yönetimlerin, vatandaşların katılım olanaklarını artırdığı ve onlara yönetimde yer vererek eğitimde bulundukları için demokratik sistemin temel ve vazgeçilmez birimleri olduğu söylenebilir. Bu bakımdan değerlendirildiğinde, büyükşehir belediyesi olan kentlerdeki il özel idarelerinin, belde belediyelerinin, köylerin tüzel kişiliğini sona erdiren bu değişimin katılımcı ve vatandaş odaklı yerel yönetim anlayışına katkıda bulunup bulunmayacağı tartışmalıdır.

Büyükşehir belediyeleri aslında aralarında hiyerarşi olmamasına rağmen, yerel yönetim birimleri arasında, eşitler arasında birinci olarak, merkezi yönetim ile ilçe belediyeleri arasında aslında bölge yönetimine benzetilebilecek yeni bir kademe haline gelmiştir. Bu durum büyükşehir belediyelerinin, kendi gücünü kullanarak yerelde daha güçlü olmasına sebep olabilir.

Son olarak merkezi yönetimin yereldeki denetiminin artması katılımcı ve müzakereci demokrasi uygulamalarının dünyada yaygınlık gösterdiği, hizmette yerindenlik anlayışının gittikçe güçlendiği bir dönemde yapılması çelişki oluşturmaktadır. Yerelde kamusal hizmetlerin sağlanmasındaki anlayış değişimi pek çok alanda merkezi yönetimin yetkileri ile görevlerini azaltıp yerel yönetimlere aktarmasını hedeflese de son kanuni düzenlemenin model olarak yerel yönetim birimlerinin güçlenmesi ile merkezi yönetimin küçülmesi hedefiyle uyumlu olmadığı söylenebilir. Bu tespitler göz önüne alınarak 6360 Sayılı Kanun hakkında gerekli düzenlemelerin yapılması ve bütünşehir uygulamalarına bu düzenlemeler yapılarak gidilmesi daha doğru olacaktır. 


\section{Kaynakça}

Arıkboğa, E. (2013). Geçmişten Geleceğe Büyükşehir Belediye Modeli. Konya: Yerel Politikalar Dergisi, Y1l 1, Sayı 3.

Aytaç, F. (1990). Belediye Kanununun Oluşumu Uygulanması ve Değişiklikler, Türk Belediyeciliğinde 60. Yıl Uluslararası Sempozyum, Bildiri ve Tartışmalar. Ankara: Ankara Büyükşehir Belediyesi.

Bae, J., Feiock, R. C. (2012). Managing Multiplexity: Coordinating Multiple Services at a Regional Level. State and Local Government Review, 44 (2).

Çapar, S., Demir, R. (2017). Türkiye'de Büyükşehir Yapılanması ve 6360 Sayılı Kanuna Uygulayıcıların Bakışı. Türk İdare Dergisi, Sayı, 484.

Çelikyay, H. (2014). Değgişen Kent Yönetimi ve 6360 Sayılı Büyükşehir Yasası. İstanbul: Seta Analiz, Sayı: 101.

Derdiman, R. C. (2012). Türkiye'de Büyükşehir Belediyelerinin ve Bu Belediyelerin Yapılarındaki Yeni Değişikliklerin Anayasaya Uyumu Sorunu. Süleyman Demirel Üniversitesi Hukuk Fakültesi Dergisi, Cilt: 2, Sayı: 1.

Erençin, A. (2005). Büyükşehirlerde Belediyeler Arası İlişkilerin Yenilenen Yapısı. Ankara: Mülkiye Dergisi, Cilt 29, Sayı 246.

Ertaş, H. (2016). Türkiye'de Yerel Yönetim Birimlerinin Görev ve Sorumlulukları İle İlgili Mevzuat ve Karşılaştırmalı Analiz. Selçuk Üniversitesi Sosyal ve Teknik Araştırmalar Dergisi, Sayı: 11.

Eryılmaz, B. (2009). Kатu Yönetimi - Düşünceler, Yapılar, Fonksiyonlar. Ankara: Okutman Yayıncilık

Frey, W., Zimmer, Z. (2001). Defining the City, Handbook of Urban Studies. Londra: Sage.

Görmez, K. (1993). Türkiye'de Anakent Yönetiminin Sorunları. Çağdaş Yerel Yönetimler Dergisi, Cilt:2, Say1: 1.

Gül, H., Batman, S. (2013). Dünya ve Türkiye Örneklerinde Metropoliten Alan Yönetim Modelleri ve 6360 Sayılı Yasa. Yerel Politikalar Dergisi, Sayı: 3.

İnceoğlu, M. (2012). Büyükşehir Planlaması ve Yönetimi, Şehircilik. Eskişehir: Anadolu Üniversitesi, Yayın No: 2559.

İsbir, E. (2012). Büyükşehir Yönetimi ve Hizmetleri, Kentleşme ve Konut Politikaları. Eskişehir: Anadolu Üniversitesi, Yayın No: 2559.

İzci, F., Turan, M. (2013). Türkiye'de Büyükşehir Belediyesi Sistemi ve 6360 Sayıl Yasa ile Büyükşehir Belediye Sisteminde Meydana Gelen Değişimler. Isparta: Süleyman Demirel Üniversitesi İktisadi ve İdari Bilimler Dergisi, Cilt 18, Sayı 1.

Keleş, R. (1985). Türkiye'de Anakent Yönetimi. Ankara: Amme İdaresi Dergisi. Sayı: 18/2.

Kıray, M. (1998). Kentleşme Yazıları. İstanbul: Bağlam Yayınları.

Kübler, D., H. Heinelt. (2005). Metropolitan Governance, Democracy and the Dynamics of Place. Londra-New York: Routledge. 
Oktay, T. (2016). Metropol Kent Yönetimi Yaklaşımları ve Uygulama Modelleri. Strategic Public Management Journal, Cilt 2, Say1 4.

Özer, M. A., Akçakaya, M. (2014). Yerel Yönetimler - Teorik Boyut. Ankara: Gazi Kitapevi.

Özgür, H. (2008). Metropoliten Alanların Yönetimine Kamu Tercihi ve Klasik Yönetim (Metropoliten Reform) Yaklaşımlarının Bakışları. Yerel Siyaset Dergisi, Sayı 30.

Soyda, Ö. M., Türk, Ş. Ş. (2012). Yeni Yasal Düzenlemelerle Büyükşehir Belediyesi Olma Kriterleri ve Sinır Tespitinin Değerlendirilmesi. Ankara: 3. Kentsel ve Bölgesel Araştırmalar Sempozyumu Bildiri Kitabı.

Tekin, Ö. F. (2018). Türkiye'de Büyükşehir Yönetimi ve 6360 Sayılı Yasanın Getirdiği Değişim: Konya Örneği. Dumlupınar Üniversitesi Sosyal Bilimler Dergisi, Sayı: 55.

Tiebout, C. M. (1956). A Pure Theory of Local Expenditures. USA: Journal of Political Economy. Issue, 64 .

Türel, A., Günay, B. (1987). Ankara Metropoliten Alanında Yerleşme Deseni. Ankara 1985'den 2015'e ODTÜ Şehir ve Bölge Planlama Bölümü Çalışma Grubu. Ankara: Ajans İletişim.

Üçer, A. G., Yenigül, S. B., Varol, Ç. (2014). Büyükşehir'den Bütünşehir'e: Yerel Yönetim Politikalarındaki Değiş̧imin Kırsal Alana Etkileri. İdealkent Dergisi, Sayı 12.

Yenigül, S. B., Çamur. K. C. (2012). Türkiye'de Metropoliten Alan Yönetimine İlişkin Yasal Düzenlemeler: Ankara Metropoliten Alan İncelemesi. Ankara: 3. Kentsel ve Bölgesel Araştırmalar Sempozyumu Bildiri Kitabı.

Zengin, O. (2014). Büyükşehir Belediyesi Sisteminin Dönüşümü: Son On Yılın Değerlendirmesi. Ankara: Ankara Barosu Dergisi, Sayı: 2. 